\author{
F. Covelo, F. Sales, M. M. V. G. Silva \& C. A. Garcia
}

\title{
Vegetation on limestone versus phyllite soils: a case study in the west Iberian Peninsula
}

\begin{abstract}
Covelo, F., Sales, F., Silva, M. M. V. G. \& Garcia, C. A.: Vegetation on limestone versus phyllite soils: a case study in the west Iberian Peninsula. - Fl. Medit. 27: 159-173. 2017. — ISSN: 1120-4052 printed, 2240-4538 online.

The influence of soil on plant cover was investigated in two different soil types, on limestone and on phyllite, in the Coimbra peri-urban area. Two areas were selected in each soil type. Soil was analysed for colour, $\mathrm{pH}$, electrical conductivity, moisture, organic matter content, mineralogy, texture and chemical composition. Floristic composition was assessed and abundance was calculated using DAFOR methodology. Data were statistically analysed in Canoco for Windows 4.5. The two soil types have distinct texture and distinct mineralogical, physical and chemical properties. Soil on limestone had $\mathrm{pH}$, electrical conductivity and moisture content higher than soil on phyllite; the latter had higher organic matter content. Soil on limestone had silt clay loam texture and the most abundant minerals were calcite and quartz. The texture of soil from phyllite is sandy loam, loam and silt loam and the most abundant minerals were quartz and mica. Also, most common oxides and trace elements are different. A total of 288 taxa in 61 families (Fabaceae, Asteraceae, and Poaceae are predominant) were identified, showing the enormous diversity of the peri-urban vegetation of Coimbra. A clear distinction was found between the vegetation of the areas of limestone and phyllite; the main environmental factors influencing the ordering of species are $\mathrm{pH}$, mineralogy and anthropic impact.
\end{abstract}

Key words: multivariate analysis, Portuguese vegetation, soil on limestone, soil on phyllite, soil properties vs vegetation.

\section{Introduction}

Soils are natural bodies and their properties derive from the combined effect of physical, chemical and biological processes acting on the parent rock material over time. The resulting mineral and organic material is essential to living beings (Blum \& al. 2006). Often, soil provides a satisfactory environment for plant growth and long term establishment of plant populations. Root growth, development and distribution across the soil profile are affected by soil chemical composition (Gregory 2006). There is evidence that in the process of land colonisation, plant lineages adapted differently to the variety of soils (Osaki \& al. 2003; Kenrick \& Strullu-Derrien 2014). 
Plants prefer simple elements, easy to absorb by osmosis. N, P, K, Ca, Mg are the main nutrients and $\mathrm{Fe}, \mathrm{Mn}, \mathrm{Zn}, \mathrm{Cu}, \mathrm{Mo}$ and $\mathrm{B}$ are essential micro nutrients (Johnston 2005). Soil with high clay content is more fertile because of its ability to adsorb nutrients; sandy soil is well drained and tends to have higher temperature. Organic matter corrects nutrient deficiencies, but in high concentration can lower the soil $\mathrm{pH}$ due to increase in organic acids during decomposition (Rheinheimer \& al. 2000). Soil pH indicates the activity of the ion hydrogen in solution. Low $\mathrm{pH}(<4.5)$ promotes the dissolution of elements such as $\mathrm{Al}, \mathrm{Fe}$, $\mathrm{Mn}$ that may attain toxic concentrations for plants; high $\mathrm{pH}(>8.0)$ turns other elements less absorbable, e.g. Fe, Mn, Zn. Salts in high concentration are also toxic and their content is assessed by determination of the electric conductivity (Brady \& Weil 2012).

In the area of Coimbra (central Portugal, c. $40 \mathrm{~km}$ from the Atlantic coast) (Fig. 1), there are two different types of soil exceptionally close to each other: (1) one developed in the Jurassic carbonate sediments (limestone, marls, marly limestone, limy marls) belonging to the Mesocenozoic Lusitanian Basin, and (2) the other developed in the phyllite of Coimbra - Espinhal - Alvaiázere sector of the Ossa Morena zone, of Neoproterozoic age, belonging to the Iberian Massif (Serviços Geológicos de Portugal 1992). These carbonate sediments and phyllite run NNW-SSE almost parallel to each other and are separated by a narrow strip (400 - $1300 \mathrm{~m}$ wide) of a Triassic sandstone (Grés de Silves) that widens south of Coimbra (Serviços Geológicos de Portugal 1992). The soils in the area are poorly developed (C-horizon is about 40-50 cm deep) and they are classified as calcaric cambisols in the limestone areas and chromic cambisols in the phyllite areas (Soil Atlas of Europe 2005).

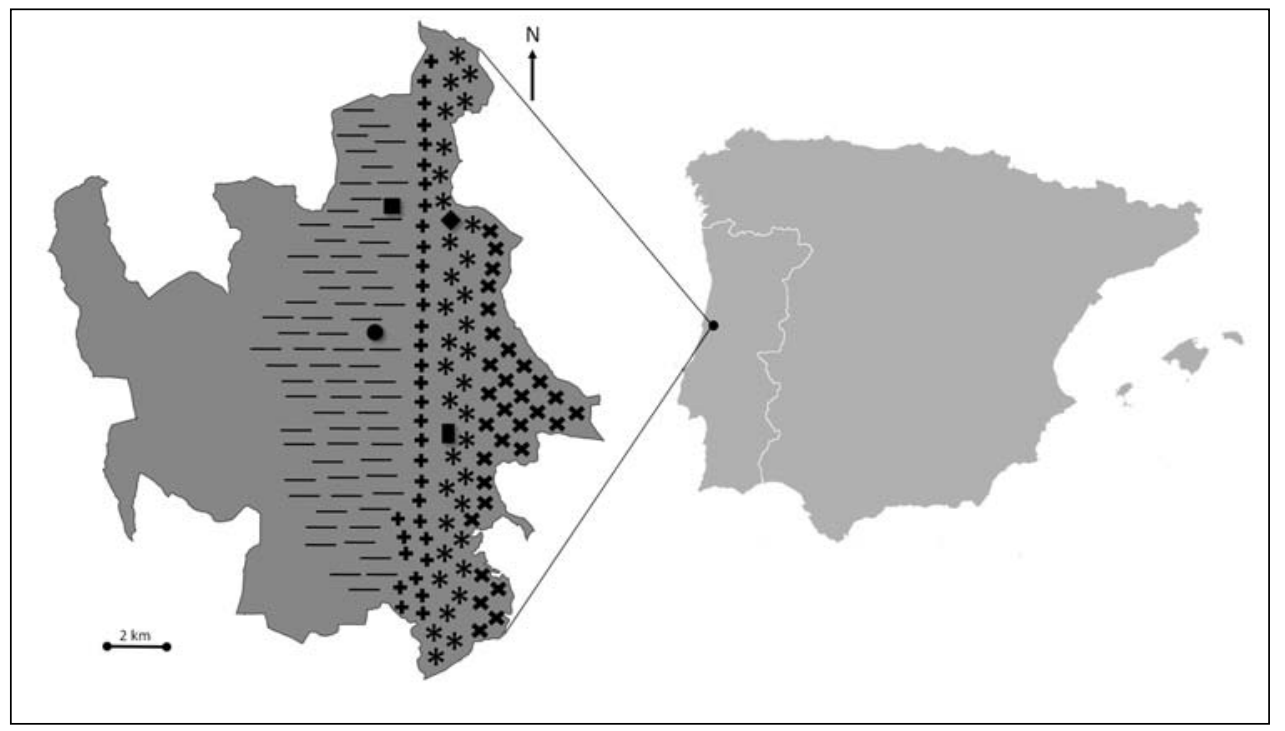

Fig. 1. Location of the areas investigated and soil types in Coimbra district. Relvinha; Souselas; Bostelim; : Torres do Mondego. ___ Jurassic carbonate sediments (limestone, marls, marly limestone, limy marl); 4: Triassic sandstone (Grés de Silves); *: Neoproterozoic phyllite of the Coimbra-Espinhal-Alvaiázere sector of the Ossa Morena zone; $\mathbf{x}$ : Neoproterozoic-Cambrian Grupo das Beiras. 
The climate of the area is within the Csb of the Köppen-Geiger climate classification (warm temperate with dry and warm summer; Pell \& al. 2007; AEMET \& IPM 2011). The vegetation falls within the Western Mediterranean sub-region, Mediterraneo-iberoatlantic superprovince of Rivas-Martinez (1987).

The main objective of this investigation was to compare the floristic composition in two soil types, on limestone and on phyllite, by selecting sites as near as possible to the spatial limit between the soils. Due to their proximity, climate should not be a factor causing variation in the floristic composition. Therefore, this area constitutes a model to study the influence of soil type on plant cover. The area also has a rich native flora in spite of locally anthropic.

\section{Materials and methods}

\section{Area selection}

The criteria to select the areas for the study in limestone and phyllite were: proximity between the two soil types and similar altitude in both soil types. In addition, the choice had to fall on sites with the least possible anthropic disturbance. Four areas (Fig. 1) were selected and they total $33,600 \mathrm{~m} 2$ for each of the two soils: on limestone, (1) Relvinha (13,600 m2; altitude: 52-91 m; Lat.: 40¹3'57.28"N, Long.: $\left.8^{\circ} 26^{\prime} 2.88^{\prime \prime} \mathrm{W}\right)$, well-developed herb, shrub and arboreal strata; long-abandoned olive grove; and (2) Souselas (20,000 m2; alt. 62-106 m; Lat.: $40^{\circ} 16^{\prime} 50.59^{\prime \prime} \mathrm{N}$, Long.: $8^{\circ} 24^{\prime} 49.28^{\prime \prime} \mathrm{W}$ ), herb and small shrub strata; on phyllite, (3) Bostelim (13,600 m2; alt. $200 \mathrm{~m}$; Lat.: 40¹6'34.21"N, Long.: $\left.8^{\circ} 23^{\prime} 19.76^{\prime \prime} \mathrm{W}\right)$, herb, shrub and arboreal strata present with the latter very well-developed height-wise; crossed by a path and partially occupied by a fallow-field; and (4) Torres do Mondego (20,000 m2; alt. 53-88 m; Lat.: $40^{\circ} 11^{\prime} 16.91^{\prime \prime}$, Long.: $\left.8^{\circ} 23^{\prime} 40.22^{\prime \prime} \mathrm{W}\right)$, very dense shrub and well-developed arboreal strata.

\section{Soil sampling and analysis}

In each of the four areas, three soil samples were collected (e.g. Relvinha 1, Relvinha 2 and Relvinha 3), each being a composite sample of 4 sub-samples. The proceeding was as follows: the O-horizont in an area of about $1 \mathrm{~m}^{2}$ was removed and 4 small excavations were performed, at about $20-30 \mathrm{~cm}$ depth, to access the B-horizon, which was sampled. These 4 sub-samples were mixed to create a composite sample.

The weight of each composite sample was c. $3 \mathrm{~kg}$. The samples were oven dried at $40^{\circ} \mathrm{C}$, sieved through a $2 \mathrm{~mm}$ nylon mesh sieve and quartered to obtain the laboratory samples, with c. $200 \mathrm{~g}$ each. The samples were analysed for methodologies readily available at the Earth Sciences Department, University of Coimbra: (1) colour, (2) pH, (3) electrical conductivity, (4) soil moisture, (5) organic matter, (6) mineralogy by X-ray diffraction, (7) chemical composition by X-ray fluorescence and (8) texture.

Soil colour was determined comparing with the Munsell Soil Color Chart (1994). Assessment of $\mathrm{pH}$ was in a 2:5 suspension of soil:water. Electric conductivity was determined in the supernatant liquid of a 1:5 mixture of soil:water. The humidity content was determined by weighing the sample before and after drying at $105{ }^{\circ} \mathrm{C}$ for 24 hours. The organic matter content was determined by loss-on-ignition in a muffle furnace at $360{ }^{\circ} \mathrm{C}$ (Salehi \& al. 2011). Replicas of one sample per area were analysed for assessment the ana- 
lytical error using the methodology of Gill \& Ramsey (1997). For all these methodologies, errors were better than $4 \%$.

The portable X-ray techniques are now used by researchers in soil sciences, archaeology and biology, environment and geology (Gazley \& al. 2014; Lemiere \& al. 2014) and in this study the chemical composition of the $<125 \mu \mathrm{m}$ fraction of soil samples was determined with a portable Niton XL3t, XRF spectrometer, Thermo Scientific. In each sample three X-ray "shots" were made and the final result was the average of these, therefore the sample chemical composition is better constrained. The analytical error was estimated with replicas using the methodology of Gill \& Ramsey (1997) and it was better than $14 \%$.

Soil texture was determined according to the data from granulometric analysis, which was performed by laser granulometry using a Coulter LS 230 granulometer. The granulometric analysis was performed after the dissolution of the organic matter and carbonates by $\mathrm{H}_{2} \mathrm{O}_{2}$ and $\mathrm{HCl}$, respectively.

For the mineralogy two samples were analysed per area and was determined by X-ray diffraction using a Philips PW 3710 diffractometer, with a $\mathrm{Cu}$ tube and $40 \mathrm{kV}$ and $20 \mathrm{~mA}$ as operating conditions. The software APD 3.6J from Philips was used for peaks identification.

\section{Floristic surveys}

Surveys took place every month during 2014 with two objectives: (1) a complete checklist of the vascular plants present in the total size of the areas studied, and (2) a statistical analysis of the vegetation. The latter was performed along three N/S random transects 20 $\mathrm{m}$ long drawn in each of the four areas; along each transect four squares $10 \times 10 \mathrm{~m}$ were outlined. Taxa abundance was assessed by the DAFOR scale (Rich \& al. 2005).

Plant identification/nomenclature followed Flora iberica (Castroviejo \& al. 1986-2014). For families not yet published, we followed Nova Flora de Portugal: Asteraceae (Franco 19711984); Poaceae (Franco \& Afonso 1998). Taxa nomenclature was up-dated according to WCSP (2014), for Asteraceae to Flann (2009). Family circumscription follows APG IV (2016).

\section{Anthropic impact}

The anthropic impact is one of the environmental variables for the statistical analysis of the vegetation and its assessment was very simple. During the surveys all impacts were identified and absence/presence was determined for each area.

\section{Statistical analysis of the vegetation}

From the 45 environmental variables considered, 19 were selected: $\mathrm{pH}$, electrical conductivity, soil moisture, organic matter, sand, clay, $\mathrm{Al}_{2} \mathrm{O}_{3}, \mathrm{CaO}, \mathrm{MgO}, \mathrm{Zn}, \mathrm{Cu}, \mathrm{K}_{2} \mathrm{O}$, $\mathrm{Fe}_{2} \mathrm{O}_{3 \mathrm{t}}$, quartz, calcite, mica, rain fall, insolation, and anthropic impact. The criteria for this selection were: (1) relevance to plant development (Cerqueira 2001; Johnston 2005); (2) the few climate variables with variation between sites (insolation [Souselas and Bostelim: 2500 - 2600 hrs; Relvinha and Torres do Mondego: 2600 - $2700 \mathrm{hrs)}$ and rainfall (Souselas: $1000-1200 \mathrm{~mm}$; Bostelim: $1200-1400 \mathrm{~mm}$; Relvinha and Torres do Mondego: 800 - $1000 \mathrm{~mm}$ ) (Agência Portuguesa do Ambiente 1931-1960)].

Statistics analysis of data used CANOCO for Windows 4.5 (ter Braak \& S̈milauer 2002). Analysis started with a Detrended Correspondence Analysis (DCA) (Hill \& Gauch 1980). Gradient length of axis 1 was 3.788 indicating high 6-diversity (McCune \& al. 
2000) and, therefore, it was performed a Canonical Correspondence Analysis (CCA). To better understand the stronger correlations taxa/ environmental variables, a weight range of $30 \%$ for the most abundant species was applied to the same CCA. The 19 environmental variables were analysed in a Monte Carlo test for significance $\mathrm{p}<0.05$ and a meaningful interpretation from the ecological point of view. The matrix of the environmental variables was created using mean values since the soil samples per area (three) were fewer than the quadrats (12). It was performed a Correspondence Analysis (CA) for species and quadrat ordination according to floristic affinity.

\section{Results}

\section{Soil analysis}

SOIL COLOUR. In Relvinha the soil is light yellowish brown (10 YR 6/4); in Souselas very pale brown (10 YR 7/3) and pale brown (2.5 Y 4/7); in Bostelim yellow (10 YR 7/6; 2.5 Y 7/6); Torres do Mondego light reddish brown (2.5 YR 7/4) and light red (2.5 YR 6/8).

PH (Table 1). The soil in the two limestone areas were strongly alkaline (Souselas $8.77 \pm$ 0.09 ; Relvinha $8.59 \pm 0.06)$ and they were moderately acid to slightly acid in the two phyllite areas (Bostelim 5.68 \pm 0.49 ; Torres do Mondego $6.34 \pm 0.39$ ), according to the Soil pH classes of the Natural Resources Conservation Service (USDA 2016).

ELECTRICAL CONDUCTIVITY (Table 1). Both soils are non-saline soils, according to USDA (2011) and the soils on limestone areas had a higher electrical conductivity (Souselas $71.40 \pm 5.63 \mu \mathrm{S} / \mathrm{cm}$; Relvinha $78.65 \pm 14.08 \mu \mathrm{S} / \mathrm{cm}$ ) than the soils on the phyllite areas (Bostelim $30.63 \pm 10.66 \mu \mathrm{S} / \mathrm{cm}$; Torres do Mondego $51.27 \pm 13.05$ $\mu \mathrm{S} / \mathrm{cm})$.

SOIL MOISTURE (Table 1). Soils on limestone areas retained more humidity (Souselas $5.47 \pm 0.84 \%$; Relvinha $4.77 \pm 0.40 \%$ ) than the soils in the phyllite areas (Bostelim 2.24 $\pm 0.48 \%$; Torres do Mondego $2.37 \pm 0.08 \%$ ).

ORGANIC MATTER (Table 1). Soil in Souselas, a limestone area, had the lowest content in organic matter $(2.49 \pm 0.55 \%)$, while the soil in Relvinha, another limestone area, had a higher organic matter content $(4.01 \pm 0.18 \%)$, approaching that of the soils in the phyllite areas (Bostelim $4.39 \pm 0.33 \%$ and Torres do Mondego $4.41 \pm 0.88 \%$ ).

TEXTURE (Fig. 2). Soil texture of the limestone areas is silty clay loam. The soil texture in the phyllite areas is more variable, with high sand content and little clay, being sandy loam, loam and silt loam.

OXIDES (Table 1). The most abundant oxide in the soil of Souselas is $\mathrm{CaO}(31.96 \pm$ $6.47 \%$ ), but the most abundant oxide in Relvinha is $\mathrm{SiO} 2(42.93 \pm 2.61 \%) . \mathrm{SiO}_{2}$ is also the most abundant oxide in the soils of the phyllite areas, being higher than in the soil of Relvinha (Bostelim $43.78 \pm 0.48 \%$; Torres do Mondego $47.63 \pm 3.70 \%$ ). Other oxides, e.g. $\mathrm{TiO}_{2}, \mathrm{Al}_{2} \mathrm{O}_{3}, \mathrm{Fe}_{2} \mathrm{O}_{3 \mathrm{t}}, \mathrm{K}_{2} \mathrm{O}$ and $\mathrm{P}_{2} \mathrm{O}_{5}$, follow the pattern of $\mathrm{SiO}_{2}$.

TRACE ELEMENTS (Table 1). The soil in the two limestone areas are also distinct in trace elements. The most abundant trace elements in Souselas soil are Sc (302.36 \pm $121.98 \mathrm{mg} / \mathrm{kg})$ and $\mathrm{Sr}(262.50 \pm 49.98 \mathrm{mg} / \mathrm{kg})$ but in Relvinha soil are $\mathrm{Zr}(237.97 \pm$ $20.11 \mathrm{mg} / \mathrm{kg})$ and $\mathrm{Cr}(175.99 \pm 9.97 \mathrm{mg} / \mathrm{kg})$. In the phyllite soil, the most abundant trace 


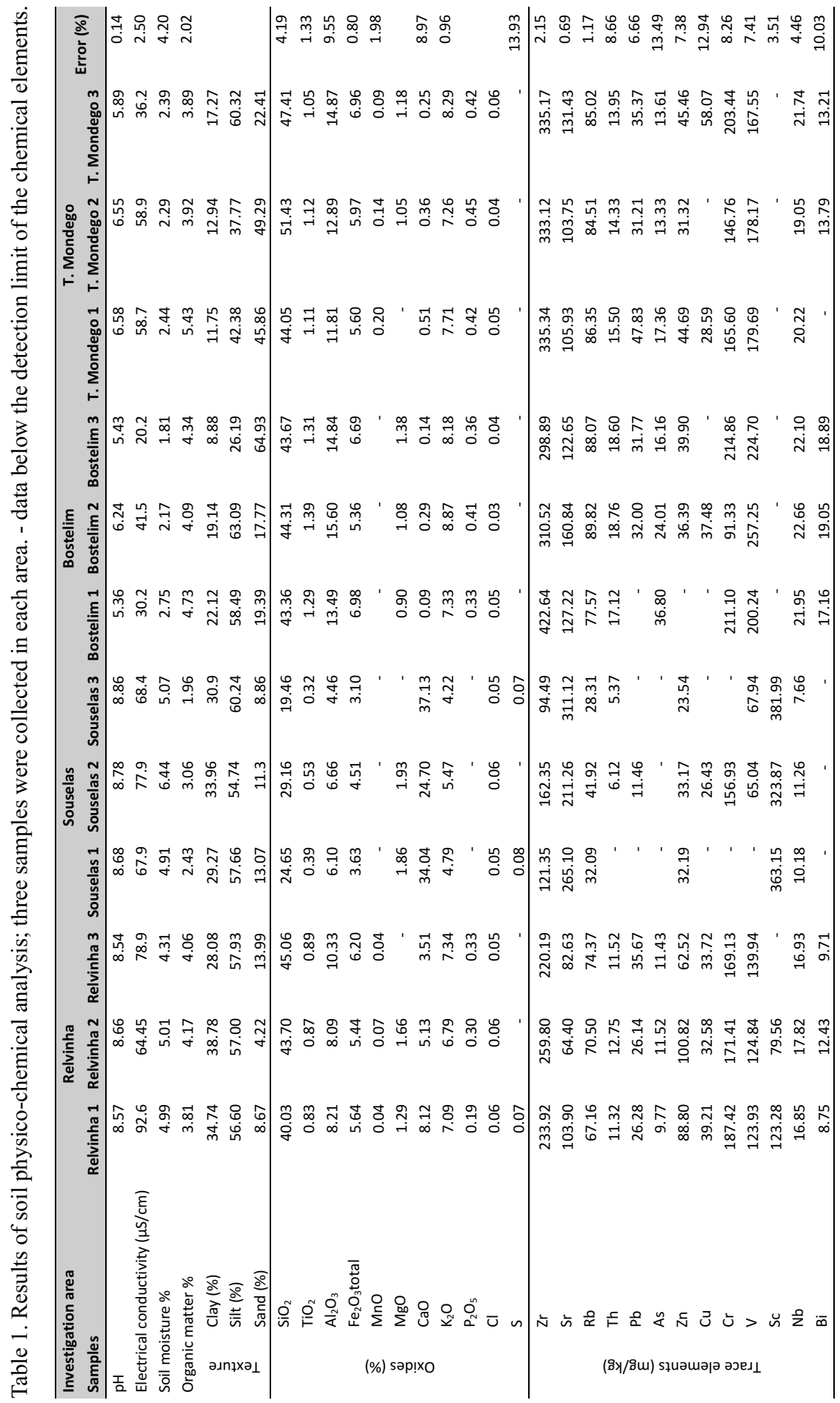




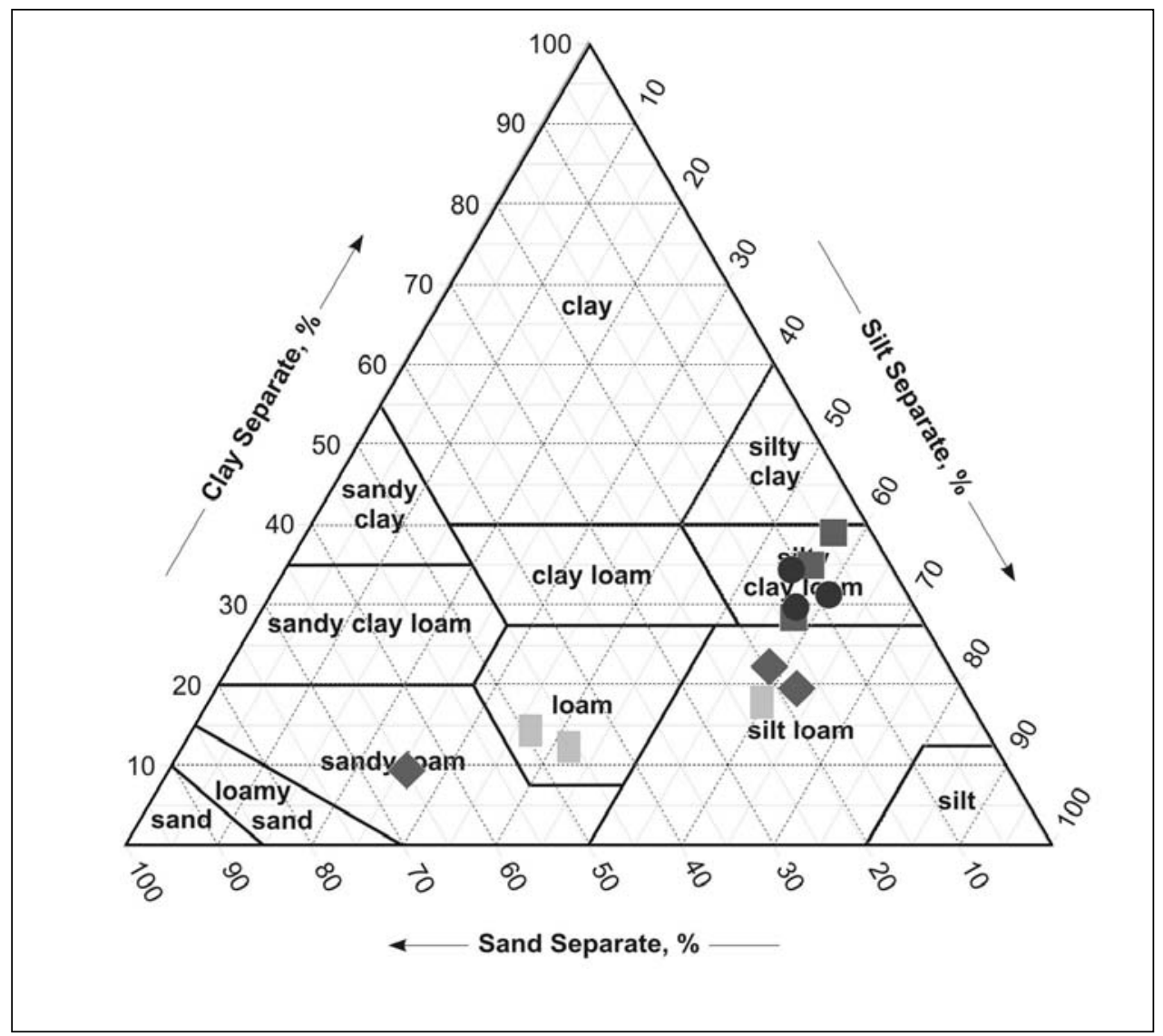

Fig. 2. Diagram of soil texture classification of the investigated areas: Torres do Mondego.

elements are $\mathrm{Zr}$ (Bostelim $344.02 \pm 68.34 \mathrm{mg} / \mathrm{kg}$; Torres do Mondego $334.54 \pm 1.24$ $\mathrm{mg} / \mathrm{kg}$ ) and $\mathrm{V}$ (Bostelim $227.40 \pm 28.60 \mathrm{mg} / \mathrm{kg}$; Torres do Mondego $175.14 \pm 6.62$ $\mathrm{mg} / \mathrm{kg}$ ). The content in $\mathrm{Zr}, \mathrm{Rb}, \mathrm{Th}, \mathrm{Pb}, \mathrm{V}, \mathrm{Nb}, \mathrm{Bi}$ follows the pattern of the oxides $\mathrm{SiO}_{2}$, $\mathrm{TiO}_{2}, \mathrm{Al}_{2} \mathrm{O}_{3}, \mathrm{Fe}_{2} \mathrm{O}_{3 \mathrm{t}}, \mathrm{K}_{2} \mathrm{O}$ and $\mathrm{P}_{2} \mathrm{O}_{5}$, i.e., being higher in soils of the phyllite areas than in the soils of the two limestone areas; here they are lower in Souselas.

MINERALOGY (Table 2). The main minerals in the four areas were quartz, mica and clay minerals in different degrees; feldspar was detected in the phyllite and in Relvinha. Soil in the limestone area of Souselas is rich is calcite and it has some quartz and mica. In contrast, soil in Relvinha has a mineralogy similar to that of the soils in the phyllite areas, in that it has high content of quartz and mica, but it has calcite and dolomite. The soils in the phyllite areas don't have calcite. The soil in Bostelim also has a small content of hematite, and the soil in Torres do Mondego has traces of titanium oxides and iron sulphides. 


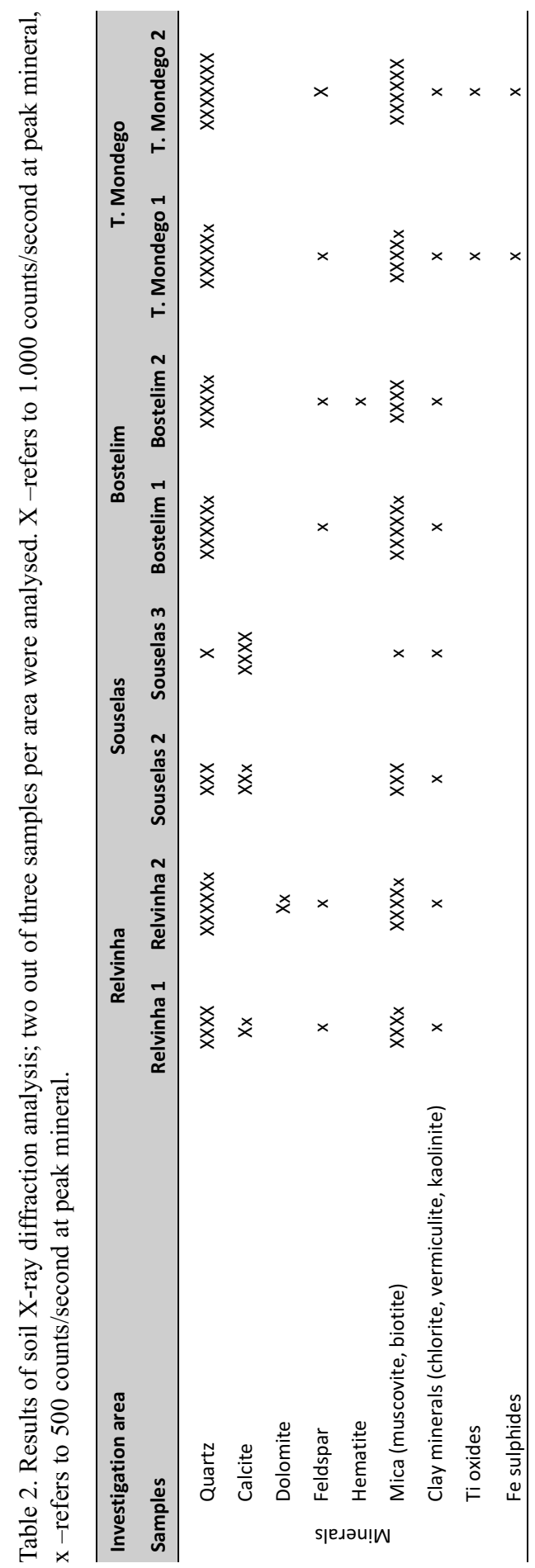




\section{Checklist}

Plant diversity was high with 288 specific and subspecific taxa identified in 190 genera and 61 families: Relvinha, 110 taxa; Souselas, 135; Bostelim, 143; and Torres do Mondego, 95 (Electronic Supplementary File 1). Bostelim has 49.65\% of the total diversity in contrast with the other much larger area in phyllite, Torres do Mondego, this having only $32.99 \%$. The largest plant families were Fabaceae, Poaceae and Asteraceae; the next most abundant were Lamiaceae and Orchidaceae. Families with more taxa in limestone were Asteraceae (Relvinha, 10\%; Souselas, 12.59\%), Lamiaceae (Relvinha, 5.45\%; Souselas, 8.89\%) and Orchidaceae (Relvinha, 4.55\%; Souselas, 8.15\%) (Table 3). Families with more taxa in phyllite were Fabaceae (Bostelim, 14.69\%; Torres do Mondego, 16.84\%), Poaceae (Bostelim, 13.99\%; Torres do Mondego, 12.63\%) and Ericaceae (Bostelim, 4.20\%; Torres do Mondego, 3.16\%) (Table 3).

Table 3. Analysis of plant diversity in the four areas. Only families with more than two taxa in at least two areas were selected; abundance (\%) at family level in each area is indicated. Families in bold are those with the highest diversity.

\begin{tabular}{lrrrrr}
\hline Family & $\begin{array}{r}\text { Relvinha } \\
\text { (\% taxa) }\end{array}$ & $\begin{array}{r}\text { Souselas } \\
\text { (\% taxa) }\end{array}$ & $\begin{array}{r}\text { Bostelim } \\
\text { (\% taxa) }\end{array}$ & $\begin{array}{r}\text { T. Mondego } \\
\text { (\% taxa) }\end{array}$ & $\begin{array}{r}\text { Total } \\
\text { of 288 taxa } \\
\text { (\% taxa) }\end{array}$ \\
\hline Apiaceae & 3.64 & 5.19 & 2.10 & 3.16 & 3.47 \\
Asparagaceae & 2.73 & 2.96 & 2.10 & 3.16 & 2.08 \\
Asteraceae & 10.0 & $\mathbf{1 2 . 5 9}$ & $\mathbf{1 1 . 1 9}$ & $\mathbf{8 . 4 2}$ & $\mathbf{1 0 . 4 2}$ \\
Caprifoliaceae & 4.55 & 2.22 & 2.10 & 1.05 & 1.74 \\
Cistaceae & 2.73 & 2.96 & 2.80 & 3.16 & 2.43 \\
Ericaceae & 1.82 & 0.0 & 4.20 & 3.16 & 2.43 \\
Fabaceae & 10.91 & $\mathbf{8 . 8 9}$ & $\mathbf{1 4 . 6 9}$ & $\mathbf{1 6 . 8 4}$ & $\mathbf{1 4 . 2 4}$ \\
Fagaceae & 1.82 & 0.0 & 2.10 & 3.16 & 1.04 \\
Gentianaceae & 2.73 & 2.22 & 2.10 & 1.05 & 1.74 \\
Lamiaceae & 5.45 & 8.89 & 4.20 & 3.16 & 5.9 \\
Orchidaceae & 4.55 & 8.15 & 0.70 & 1.05 & 4.51 \\
Plantaginaceae & 0.91 & 2.22 & 2.10 & 1.05 & 2.08 \\
Poaceae & $\mathbf{1 1 . 8 2}$ & $\mathbf{8 . 1 5}$ & $\mathbf{1 3 . 9 9}$ & $\mathbf{1 2 . 6 3}$ & $\mathbf{1 1 . 1 1}$ \\
Rosaceae & 5.45 & 4.44 & 4.20 & 5.26 & 3.13 \\
Rubiaceae & 1.82 & 2.96 & 2.80 & 2.11 & 1.74 \\
\hline Total & 70.92 & 71.85 & 71.36 & 68.42 & 68.06 \\
\hline
\end{tabular}

\section{Statistical analysis of the vegetation}

The matrix of taxa abundance (DAFOR data) refers to 196 taxa in 48 squares in a total of 1.585 entries. 
Table 4. Anthropic impacts identified in the areas investigated. Totals were used in the matrix of environmental variables. X: presence of anthropic impact.

\begin{tabular}{lcccc}
\hline Impact & Relvinha & Souselas & Bostelim & T. do Mondego \\
\hline Agriculture & & & $X$ & \\
Desflorestation & & & $X$ & \\
Fallow field & $X$ & $X$ & $X$ & \\
Grazing & & $X$ & $X$ & 0 \\
Motor traffic & & 2 & 5 & \\
\hline Totals & 1 & & &
\end{tabular}

Table 5. Values of F e P (test de Monte Carlo, with 499 simulations) and inflation factor of environmental variables selected for the preparation of the CCA.

\begin{tabular}{lccc}
\hline Environment variables & Inflation factor & $\mathbf{F}$ & $\mathbf{P}$ \\
\hline $\mathrm{pH}$ & 5.8541 & 10.05 & 0.0020 \\
Mica & 4.3007 & 6.43 & 0.0020 \\
Anthropic impact & 2.2951 & 8.05 & 0.0020 \\
\hline
\end{tabular}

Table 6. CCA and CA ordination summary.

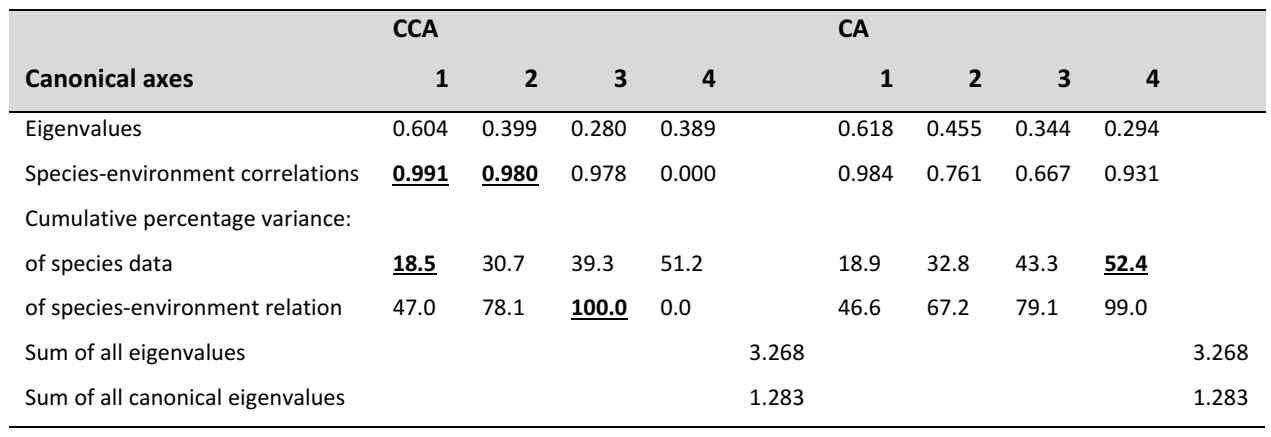


For the CCA ordination the environmental variables selected from the Monte Carlo test were $\mathrm{pH}$, mica content of soil and anthropic impact (Table 4), all with $\mathrm{p}=0.002$; a selection of 10 from the remaining 16 variables was used as supplementary variables in the analysis. The inflation factor of the environmental variables that explain species ordination is $<10$ which indicates a desirable low multicollinearity between them (Table 5). The CA explains $52.4 \%$ of the total floristic variation found amongst the four areas (Table 6). As the eigenvalues of CA and CCA are similar in the first four axes, the environmental variables included in the CCA explain the floristic variation found in the CA.

The CCA ordination shows different groups along the first and second axes. Along axis 1 are separated the areas of limestone and phyllite. The two limestone areas, Souselas and Relvinha, are very close to each other and are positively correlated with $\mathrm{pH}$, electrical conductivity, soil moisture, calcite and clay; the two areas of phyllite, Bostelim and Torres do Mondego, are positively correlated with mica, $\mathrm{K} 2 \mathrm{O}$, organic matter and quartz. Along axis 2 are separated the two areas of phyllite, Bostelim having a positive correlation with both anthropic impact and rainfall (Electronic Supplementary File 2).

In the CA ordination, species and quadrats have a similar relation to that in the CCA, although the quadrats overlap in the CCA but split in the CA. The quadrats in Bostelim are clearly split in two groups in the CA (Electronic Supplementary File 3).

\section{Discussion}

\section{Soil analysis}

Soil $\mathrm{pH}$ and soil electrical conductivity of soil influence the amount of salts available to plants. The differences in $\mathrm{pH}$ found in the two soil types studied are mainly due to the mineral composition of soils, which is controlled by lithology. Electrical conductivity is proportional to the content in soluble salts. In the limestone soils, both $\mathrm{pH}$ and electrical conductivity are high, due to easy calcium carbonate dissolution that causes higher $\mathrm{pH}$ and higher content in dissolved salts.

In the two limestone areas, the soil has higher clay content (c. 32.62\%). This soil type influences plant development in different ways. The little permeability of such soil leads to the accumulation of water at the surface and reduces infiltration to lower horizons. Water accumulated in small depressions explains the local presence of a few Cyperaceae. On slopes, overland flow takes place and the soil becomes drier, which explains the presence of Carlina gummifera, a species adapted to water stress (Barceloux 2012). This soil with small macro-porosity is compact and, therefore, with little oxygen.

The soils on the two phyllite areas are loamy and silt-loamy with lower clay and higher sand content $(36.61 \%)$ than in the limestone areas $(10.02 \%)$. Because of their higher permeability and macro-porosity, water runs through them quicker and, therefore, they are drier than the soil of Relvinha and Souselas. Soils with a silty to sandy loam texture have a cation exchange capacity (CEC) of 10-15 meg/100g, while clay loams have a CEC of 15-30 $\mathrm{meq} / 100 \mathrm{~g}$ (Donahue $\&$ al. 1977), but the soils in the phyllite areas have higher organic matter content $(4.39-4.41 \%)$, than the soils in the limestone areas $(2.49-4.01 \%)$. As organic matter has a much higher cation exchange capacity e.g. CEC of 150-500 meq/100g (Birkeland 1974), the soils in the phyllite areas will have higher contents of available nutrients. In fact, 
essential elements to plant development, such as Zn, K, P and Fe (Johnston 2005), are in higher concentration in the soils of the phyllite areas than in the soils of the limestone areas.

The lower content in organic matter of the soils in Souselas may result from its mildly alkaline $\mathrm{pH}$, enough to favour the soil decomposers (Andrews \& al. 2003). The higher content in organic matter in the soils from Relvinha and from the two phyllite areas (Bostelim and Torres do Mondego) may also be explained by the vegetation itself, here with greater development of the shrub stratum.

Soils from the phyllite areas have higher concentrations of $\mathrm{SiO}_{2}, \mathrm{TiO}_{2}, \mathrm{Al}_{2} \mathrm{O}_{3}$, total $\mathrm{Fe}_{2} \mathrm{O}_{3}$, $\mathrm{K}_{2} \mathrm{O}$ and $\mathrm{P}_{2} \mathrm{O}_{5}$ and lower concentrations of $\mathrm{CaO}$, than soils from the limestone areas (Table 2). These differences, evaluated with t-Student test, are statically significant and they are explained by differences in the lithology of the parent material. In these cambisols the parent material seems to be the main factor controlling the chemical composition of the soils. This is also true for trace elements as the soils from the phyllite areas have statistically higher contents of $\mathrm{Zr}, \mathrm{Rb}, \mathrm{Th}, \mathrm{V}$ and $\mathrm{Nb}$ than soils from limestone areas (Table 1) and these have an average of $254.37 \mathrm{mg} / \mathrm{kg}$ of Sc, which was not detected in the soils from the phyllite.

Altogether, the results of soil analysis showed that in the two phyllite areas (Bostelim and Torres do Mondego) the soils have similar composition but that there are various differences between the soils in the two limestone areas (Relvinha and Souselas). The soil from Relvinha has a chemical composition more similar to the soils from the phyllite areas, than the soil from Souselas (Table 1). This can be explained by two factors: 1) the parent material in Relvinha has an higher marl content than in Souselas; 2) in Relvinha the soil has a transported component, derived from a terrace deposit of red sands (Areias Vermelhas do Ingote, Soares \& al. 1985), located at higher altitude, above up-stream Relvinha, as quartz pebbles were identified during field work in this soil.

\section{Checklist}

The most abundant families are Fabaceae (14.24\%), Poaceae (11.11\%) and Asteraceae $(10.42 \%)$, the typical pattern in the Mediterranean (Table 3), which compares very well with a nearby area (Barrico \& al. 2012). An indicator used for the degree of the Mediterranean influence is the index of Cistaceae (Cueto \& al. 1991). It is considerably high $(2.43 \%)$ (Table 3$)$ in the areas here studied, even higher than in Southern Iberian Peninsula (2.30\% in Almeria; Cueto \& al. 1991).

Proportionally to the size of the areas, species number in the soils from the limestone areas is quite similar, whereas it is very disparate in the soils from phyllite areas. Bostelim has the highest species number (143) of the four areas and Torres do Mondego has the lowest (95) (Electronic Supplementary File 1). Torres do Mondego has very steep topography were slope is $40 \%$ and, therefore, anthropic impact is the lowest of all areas (Table 4). Native vegetation has developed well, mainly trees and shrubs, e.g. Arbutus unedo, Cistus salviifolius, Erica arborea, Myrtus communis, Quercus suber (Electronic Supplementary File 2) leaving little space for annuals. The high species number in Bostelim is discussed in the sections below.

\section{Statistical analysis of the vegetation}

Species ordination is not substantially altered in presence of the environmental variables (compare CCA and CA, Electronic Supplementary File 2 and Electronic Supplementary 
File 3). This means that the environmental variables in the CCA are the explanation for the floristic composition of the areas. The differences between CCA and CA result from the use of averages for each environmental variable; this leads to the observed grouping of quadrats in each area in the CCA.

The differences in mineralogy and physico-chemical composition of the soils explain the clear separation of both the limestone and phyllite areas along the axis 1 in the CCA (Electronic Supplementary File 2).

Along the axis 2 of the CCA are observed major contrasts between the soils in limestone and phyllite areas. Whereas the two limestone areas are very close to each other, the two phyllite are further apart (Electronic Supplementary File 2). Although the soil analysis showed differences between the two limestone areas greater than those between the phyllite, the vegetation composition does not seem to be affected (at least in the analysis) by such differences. The major distance along the axis 2 between the two phyllite areas does not result from the soil features (mica, $\mathrm{K}_{2} \mathrm{O}$, organic matter, quartz). In fact, the anthropic impact shows its highest strength in the direction of Bostelim placing it away from its counterpart, Torres do Mondego. In fact, many of the species restricted to Bostelim are ruderal taxa, e.g., Digitalis purpurea subsp. purpurea, Medicago polymorpha, Raphanus raphanistrum subsp. raphanistrum, Rumex bucephalophorus subsp. hispanicus and Vicia sativa subsp. sativa. In the CA ordination, it is clear the heterogeneity of Bostelim itself with one transect placed a long distance away in axis 2 (Electronic Supplementary File 3). This transect is a small fallow field and the human impact here is evident in the higher number of annuals.

The analysis showed a number of taxa with stronger affinities to particular environmental variables. These taxa are densely placed around the respective squares (Electronic Supplementary Files $2 \& 3$ ). To better understand the stronger correlations taxa/kind of soil, the same CCA is also given with a weight range of $30 \%$ for the most abundant species (Electronic Supplementary File 4).

\section{Conclusions}

Plant diversity was dissimilar in the two soil types studied, one developed from limestone, the other from phyllite. Different parent materials have determined different soil mineralogy, thus different soil proprieties that, in turn, influenced the vegetation structure and floristic composition.

The variability of soil proprieties in the limestone areas did not substantially alter the floristic composition.

The decisive environmental variable for the differences in floristic composition between the two phyllite areas was the stronger anthropic impact observed only in one of them.

\section{Acknowledgements}

We thank Prof. José P. Sousa, Dpt Life Sciences, University of Coimbra, for his valuable advice on the statistical treatment. We would also like to thank Ian C. Hedge, Honorary Associate of the Royal Botanic Garden Edinburgh, for revising the English. We are grateful for the comments of the referees to the manuscript. 


\section{References}

AEMET \& IPM. 2011: Atlas climático Ibérico: temperatura do ar e precipitação (1971-2000). Madrid.

Agência Portuguesa do Ambiente 1931-1960: Atlas do ambiente - Ministério da agricultura, do mar, do ambiente e do ordenamento de território. http://snig.dgterritorio.pt/portal/ [Last accessed 01/06/2017]

Andrews, J. E., Brimblecombe, P., Jickells, T. D., Liss, P. S. \& Reid, B. 2003: An Introduction to Environmental Chemistry,. $2^{\text {nd }}$ ed. - New Jersey.

APG IV. 2016: An update of the Angiosperm Phylogeny Group classification for the orders and families of flowering plants: APG IV. - Bot. J. Linn. Soc. 181: 1-20. doi: 10.1111/boj.12385

Barceloux, D. G. 2012: Medical Toxicology of Natural Substances: Foods, Fungi, Medicinal Herbs, Plants, and Venomous Animals. - New Jersey.

Barrico, L., Azul, A. M., Morais, M. C., Coutinho, A. P., Freitas, H. \& Castro, P. 2012: Biodiversity in urban ecosystems: Plants and macromycetes as indicators for conservation planning in the city of Coimbra (Portugal). - Landscape Urban Planning 106: 88-102.

Birkeland, P. W. 1974: Pedology, Weathering and Geomorphological Research. - Oxford.

Blum, W. E. H., Warkentin, B. P. \& Frossard, E. 2006: Soil, human society and the environment. Pp. 1-8 in: Frossard, E., Blum, W. E. H. \& Warkentin, B. P., Funtion of soils for Human Societies and the Environment. Geological Society, Special Publications, 266. - London. doi:10.1144/GSL.SP.2006.266.01.01

Brady, N. C. \& Weil, R. R. 2012: Elementos da natureza e propriedades dos solos, $3^{\text {rd }}$ ed. - Porto Alegre.

Castroviejo, S. \& al. 1986-2014: Flora iberica. Plantas vasculares de la Peninsula Iberica e Islas Baleares. - Madrid.

Cerqueira, J. 2001: Solos e Clima em Portugal, $2^{\text {nd }}$ ed. - Lisboa.

Cueto, M., Blanca, G. \& González Rebollar, J. 1991: Análisis florístico de las Sierras de María y Orce (provincias de Almería y Granada, España). - Anales Jard. Bot. Madrid 48(2): 201-211.

Donahue, R., Miller, R., Shickluna, J. 1977: Soils: an introduction to soils and plant growth, $4^{\text {th }}$ ed. - New Jersey.

Flann, C. (Ed.). 2009. Global Compositae Checklist. [http:// compositae. landcareresearch.co.nz, Last Accessed 3/01/2017].

Franco, J. A. 1971-1984: Nova Flora de Portugal (Continente e Açores), 1-2. -Lisboa.

— \& Afonso, M. L. R. 1998: Nova Flora de Portugal (Continente e Açores), 3(2). - Lisboa.

Gazley, M. F., Tutt C. M., Brisbout, L. I., Fisher, L. A. \& Duclaux, G. 2014: Application of portable X-ray fluorescence analysis to characterize dolerite dykes at the Plutonic Gold Mine, Western Australia. - Geochemistry: Exploration, Environ. Anal. 14(3): 223-231.

Gill, R. \& Ramsey, M. H. 1997: What a geochemical analysis means. - Pp. 1-11 In: Gill, R. (Ed.), Modern Analytical Geochemistry: An introduction to quantitative chemical analysis techniques for earth, environmental and materials scientists. - London.

Gregory, P. 2006: Plant roots. Growth, activity and interaction with soils. - Oxford.

Hill, M. O. \& Gauch, H. G. 1980: Detrended correspondence analysis: an improved ordination technique. - Vegetatio 42: 47-58.

Johnston, A. E. 2005: Trace elements in soil: status and management. - Pp. 7-13 in: Thorvaldsson G. \& Rósa, S. J. (Eds.), Essential trace elements for plants, animals and humans. - Reykjavík.

Kenrick, P. \& Strullu-Derrien, C. 2014: The origin and early evolution of roots. - Pl. Physiol. 166: 570-580. doi: 10.1104/pp.114.244517

Lemiere, B., Laperche, V., Haouche, L. \& Auger, P. 2014: Portable XRF and wet materials: application to dredged contaminated sediments from waterways. - Geochemistry: Exploration, Environ. Anal. 14: 257-264. 
McCune, B., Rosentreter, R., Ponzetti, J. M. \& Shaw, D. C. 2000: Epiphyte habitats in an old conifer forest in Western Washington, USA. - The Bryologist 103(3): 417-427.

Munsell Soil Color Charts (1994). Revised Edition. - New York.

Osaki, M., Yamada, S., Ishizawa, T., Watanabe, T., Shinano, T., Tuah, S.J. \& Urayama, M. 2003: Mineral characteristics of leaves of plants from different phylogeny grown in various soil types in the temperate region. - Pl. Foods Human Nutr. 58(2): 117-37.

Pell, M. C., Finlayson, B. L. \& McMahon, T. A. 2007: Updated world map of the Koppen-Geiger climate classification. - Hydrol. Earth Syst. Sci. 11: 1633-1644.

Rheinheimer, D., Santos, E., Kaminski, J. \& Xavier, F. 2000: Aplicação superficial de calcário no sistema plantio direto consolidado em solo arenoso. - Ci. Rural 30(2): 263-268.

Rich, T., Rebane, M., Fasham, M., McMeechan, F. \& Dobson, D. 2005: Ground and shrub vegetation. - Pp. 201-222 in: Hill, D., Fasham, M., Tucker, P., Shewry \& M., Shaw P. (Eds.), Handbook of biodiversity methods: survey, evaluation and monitoring. - Cambridge.

Rivas-Martinez, S. 1987: Nociones de sobre fitosocilogia, biogeografia y bioclimatologia. - Pp. 1946 in: Lorca, M. P. \& Rivas-Martinez, S. (Eds.), La vegetation de España. - Madrid.

Salehi, M. H., Beni, O. H., Harchegani, H. B., Borujeni, I. E. \& Motaghian, H. R. 2011: Refining soil organic matter determination by loss-on-ignition. - Pedosphere 21(4): 473-482.

Serviços Geológicos de Portugal. 1992: Carta Geológica de Portugal 1:500000. - Lisboa.

Soares, A. F., Marques J. F. \& Rocha, R. B. 1985: Contribuição para o conhecimento geológico de Coimbra. - Mem. Not. Publ. Mus. Lab. Mineral. Geol. Univ. Coimbra 100: 41-71.

Soil Atlas of Europe, 2005. European Soil Bureau Network, European Commission. Office for Official Publications of the European Communities, Pp. 128.

ter Braak, C. J. F. \& Śmilauer, P. 2002: Canoco reference manual and CanoDraw for Windows user's guide: software for canonical community ordination (version 4.5). - Wageningen.

USDA 2011: Soil quality indicators. USDA Natural Resources Conservation Service. http://www.nrcs.usda.gov/wps/PA_NRCSConsumption/download?cid=nrcs142p2_053136\&e $\mathrm{xt}=$ pdf. [Last Accessed 8/11/2016].

— 2016: Soil pH testing and management. Natural Resources Conservation Service. United States Department of Agriculture (USDA). https://www.nrcs.usda.gov/wps/portal/nrcs/detail/national/home/?cid=nrcs144p2_057681. [Last Accessed 8/11/2016].

WCSP. 2014: World Checklist of Selected Plant Families. Facilitated by the Royal Botanic Gardens, Kew. [http://apps.kew.org/wcsp/home.do, Last Accessed 8/11/2016]

Addresses of the authors:

Filipe Covelo ${ }^{1}$, Fátima Sales ${ }^{1,2}$, Maria Manuela da Vinha Guerreiro da Silva ${ }^{3}$, César Augusto Garcia ${ }^{4}$,

${ }^{1}$ Centre for Functional Ecology, Department of Life Sciences, University of Coimbra, Calçada Martim de Freitas, 3000-456 Coimbra, Portugal. E-mail: filipe.covelo@student.uc.pt

${ }^{2}$ Royal Botanic Garden Edinburgh EH3 5LR, Edinburgh, Scotland.

${ }^{3}$ Centre for Mechanical Engineering, Department of Earth Sciences, University of Coimbra, Rua Sílvio Lima, Univ. Coimbra - Pólo II, 3030-790 Coimbra, Portugal.

${ }^{4}$ Museu Nacional de História Natural e da Ciência, Centre for Ecology, Evolution and Environmental Changes, Universidade de Lisboa, Rua da Escola Politécnica, 58, 1250-102 Lisboa, Portugal. 
